\title{
Crisis Management of Brawijaya University
}

\author{
${ }^{1}$ Arsih Amalia Chandra Permata, ${ }^{2}$ Maulina Pia Wulandari, \\ ${ }^{3}$ Rachmat Kriyantono \\ 1,2,3 Program Studi IImu Komunikasi Universitas Brawijaya, Indonesia \\ Email: amalia.permata@ub.ac.id
}

\begin{abstract}
The aim to be achieved is to know the efforts of crisis management. The research was conducted at the University of Brawijaya in 2010-2019, based on the view of the Rector of the University of Brawijaya during his tenure, as well as a plan to deal with the crisis at Brawijaya University in 2020-2025. This evaluative study was conducted using a qualitative approach and in-depth interview methods. The informant interviewed by the Chancellor who served in the period 2010-2019, the head of UB's Public Relations. The results of this study will describe or construct in-depth interviews with research subjects so that they can provide a clear picture of Crisis Management in UB since 2010-2019. The method used in this research is indepth interviews (intensive interviews) or intensive interviews (intensive interviews) and most are not structured. To maintain data quality using checking with triangulation. The results showed that the crisis at the university which was classified specifically, had not been interpreted as a crisis in the body of the organization itself, the role of public relations was also more focused on fostering good relations with the media.
\end{abstract}

Keywords: Crisis Management, Higher Education Crisis, Role of Public Relations.

\section{A. INTRODUCTION}

An early study of the crisis in tertiary institutions was one of them delivered by Salmi (1991) who stated that colleges/universities were in crisis. In many developing countries, education planners and decision makers are faced with the worrisome situation of uncontrolled registration growth and spending against a background of reduced financial resources, a decline in the quality of teaching and research, and an increase in unemployment rates at the undergraduate level. The crisis was found in terms of: 1) policy analysis, 2) construction problems, and 3) decision making regarding the higher education sub-sector. The crisis in tertiary institutions in developing countries is related to administrative, academic, student and staff staff activities.

Some examples of crises in developing countries include: a) the degradation of the work of undergraduate/college graduates. For example in Egypt, engineering graduates are required to become technicians and go down due to lack of employment; b) students and tuition fees are not appropriate. The crisis is related to student admission and free education which is not accompanied by equal employment opportunities. c) students are seen as a threat that causes political upheaval such as in South Korea, Thailand and some serious problems relating to politics in Argentina, Bolivia, Peru, Uruguay, Bangladesh, Burma, Indonesia, India, Turkey, Nigeria, Liberia, Ghana, Nigeria and Senegalese. 
Blaxter and Tight (1994) address several crises in North American tertiary institutions including teaching standards, research relevance, growth in graduation rates, racist treatment on campus, military influence on campus, industrial organization/facility savings and corruption caused by several sports facilities. In contrast, in the UK the crisis is related to public funding, vocational curriculum, government interference and antipathy. Berdahl, Moodie and Spitzberg (1991) in Tight (1994) conveyed "in North America the crisis focuses on the development/change of standards in educational practices. Whereas in America developments in the quality of education are behind it.

Zamani (2003) presents an example of a crisis in tertiary institutions with everything related to racial issues as a crucial topic of problems in the United States in the 1960s, especially after the emergence of demands relating to human rights. Racial issues often ignited mass anger/demonstrations in the 1980s, and shifted in the direction related to public policy and services in the 1990s. Examples of cases include in 1996 that $54 \%$ of students affirmatively supported the elimination of racial policies on campus. At the same time, $63 \%$ of students agreed not to express hate speech on campus, and only $12 \%$ of students stated racial problems were not a major problem in the United States. Woodson (1993) stated that most academic administrators and faculties see racial problems in a limited way, as individual crises to be dealt with specifically, not as crises that need to be followed up. On the other hand, observers of African American descent argue that racial issues have historically been ignored as a central crisis in the United States Education and society.

A crisis does not just happen, but it is a process of an event. Fink (in Sellnow and Seeger (2013) develops the stages of a crisis called the crisis development model, which consists of four stages, namely: (a) prodromal, signs or warnings of a crisis that can actually be identified and observed; (b ) acute, the stage of crisis arises and occurs, (c) chronic, the stage of recovery after the crisis occurs, (d) crisis resolution, the organization can carry out its activities normally again, even though the crisis is disastrous, on the positive side the crisis can be a force for organizations to change , growth and renewal for the better (Sellnow \& Seeger, 2013).

Other research on the crisis in tertiary institutions was carried out by (Feoktistova, 2013), who described efforts on corruption in universities in Kazakhstan and its prosperous countries. This study seeks to find the problem of corruption as a social problem that impedes the development of the education system and explains in detail the prerequisites, causes and consequences of corruption in higher education. Specific examples of various corruption cases on the basis of a brief analysis of the situation in higher education in Kazakhstan are: 1) manipulation of data for the benefit of university accreditation by independent institutions and authorities; 2) manipulation of exam results and faculty assessments by examiners; 3 ) abuse of the system for manipulation of university data for student 
graduation; 4) university education portal abuse; 5) granting fictitious grades to students who have never/rarely entered but still get grades for completeness of academic administration to student graduation requirements.

Muralidharan, Rasmussen, Patterson, and Shin (2011) argue that the public is looking for information related to crises experienced by organizations based on media coverage. Coombs (2010) mentions the importance of seeing how the media frame the crisis experienced by organizations because it will affect public perceptions and the image of the organization. Therefore, the writer assumes that the media has an important role in spreading information to his audience, namely creating opinions about the organization to the public. Ross and Fletcher (1985) in An and Gower (2009) Public perception of an event depends on the information circulating around it inside.

Universitas Brawijaya as a state university in a government institution is obliged to follow the regulations set by the government. Based on the Regulation of the Minister of State for Administrative Reform and Bureaucratic Reform of the Republic of Indonesia Number 30 of 2011 concerning General Guidelines for Public Relations Governance in Government Agencies it is known that the government's public relations task is 1 . carry out reciprocal communication between government agencies and the public planned to create mutual understanding in achieve goals, in order to obtain mutual benefits; 2. improve the smooth flow of information and public accessibility; 3 . improve coordination in disseminating information about government policies; 4 . Build a positive image and reputation.

The public relations function cannot be separated from the management activities of tertiary institutions. Ruslan (2002) in Nasution (2010) explained the requirements that must be fulfilled by public relations practitioners, including a) must have the ability to identify, analyze opinions and various issues about their institutions that occur in society; b) must have the ability to influence opinions; c) must have the ability to establish good relationships and mutual trust between the institutions / organizations they represent.

Birnbaum and Shushok Jr. (2001) convey in detail the types of crises in Higher Education namely: 1) Pandemic Crisis or pandemic crisis: an event that occurs repeatedly with high frequency. For 25 years, finance has been a major pandemic crisis at tertiary institutions. 2) Chronic crisis or chronic crisis is a crisis that arises with varying continuity and frequency. This book identifies five chronic crises which include self-confidence, curriculum, stagnation (matters relating to the attitudes of universities that are not responsive to changing needs), diversity/equity, and government leadership/management. These things become routine discussions on the tertiary policy agenda. 3) Sporadic crisis is a crisis condition related to student riots, literacy/writing, values/morals and student registration. 4) Idiosyncratic crisis or a special crisis that is a crisis relating to things that are very specific. Some of them are related to accreditation, parking lots, to collective bargaining. Crisis that falls 
into this special category is often considered a common problem by most people, but tends to be an obstacle to organizational development.

\section{B. LITERATURE REVIEW}

\section{Crisis Characteristics}

Mitroff (2001) states that there are five general characteristics of a crisis, namely: 1) A crisis results in damage to property, injury, loss of life, and/or reputation damage; 2) Crisis is detrimental and affects many people; 3) Crises have identifiable beginnings and ends; 4) Crisis is relatively sudden; 5) The crisis received wide media coverage and public attention. To manage crises as well as possible, government communicators must identify crises that arise as early as possible. Associated with the research theme, during the period of 2010-2019 the characteristics of the crisis in Brawijaya University appear to be detrimental/ affecting many people, having a beginning and end of events, relatively sudden, and not infrequently becoming the news and becoming the center of public attention.

Regarding the causes of crises, Shirivasta and Mitroff (1999) divided crises into four categories based on the causes of crises associated with the place of crisis. First, which is categorized in technical and economic causes. Second, which is categorized as a human, organizational and social cause. They also categorize the causes of the crisis from the point of view of origin or events inside or outside the organization. The causes of the crisis can be categorized into: 1) Due to human error (human error), 2) Due to technological failure, 3) Due to social reasons (riots, war, sabotage, terrorists), 4) Because it deals with natural disasters 5) Because of incompetence in management. A crisis may be caused by only one factor, but very often a crisis occurs due to a combination of the above factors.

\section{Response to Crisis}

Coombs (2010, p. 28) states that response to crisis is the most studied aspect of crisis communication. The reason is how and what the organization communicates during a crisis has a significant influence on the results of the crisis, including the number of injuries and the amount of reputation damage suffered by the organization. The response to the crisis includes:

a. Tactical advice or tactical advice. This right advice is used by the spokesperson when meeting the media. Four responses that emerged and were supported by theory and research in crisis communication and related communication fields are: a) avoiding "no comment" or "no comment." The other three responses are: b) fast, c) accurate, and d) consistent (King, 2002). Practitioners emphasize the importance of rapid responses, usually within the first hour after the event. Millner, Veil, and Sellnow (2011) say that failure to respond to a crisis provides another party with an opportunity to frame information about the crisis that is occurring and as if felt by stakeholders. 
Silence or being too passive provide opportunities for others to control the crisis.Strategic Advice atau nasihat yang tepat. Penelitian strategis berupaya memahami komunikasi krisis yang digunakan untuk mencapai hasil spesifik dan memiliki efek yang diinginkan oleh para pemangku kepentingan. Penekanannya ada pada beragam strategi respons krisis yang digunakan untuk mengejar berbagai tujuan organisasi. Sturges (1994) menyampaikan kerangka kerja yang berguna untuk mengkategorikan respons krisis dengan fokus yang tepat. Tiga fokus strategis Sturges adalah (1) menginstruksikan informasi, yakni berkaitan dengan upaya untuk mengatasi krisis secara fisik; (2) menambahkan informasi, yakni upaya mengatasi krisis secara psikologis; dan (3) perbaikan reputasi, yakni upaya untuk memperbaiki kerusakan yang ditimbulkan krisis pada suatu organisasi. Menyampaikan informasi, menurut Sturges (1994), adalah prioritas pertama dalam krisis.

b. Corporate Apologia is a rhetorical concept that explores the use of communication for self defense. Benoit (1995) conveys a person's character in question when someone is accused of being involved in an act of guilt. When an organization is attacked, one of four communication strategies can be used to maintain its character. The four strategies are denial or denial (the organization is not involved in mistakes that occur), bolstering or reinforcing (reminding the public of the good things that have been done), differentiation or differentiation (ie removing actions from negative contexts), and transcendence or transcendence (efforts to put action in a broader, more profitable new context). Crises can be seen as mistakes and create a need for "corporate apologia" or "company apologies". The company speaks to maintain its reputation. Ice (1991), Hobbs (1995), and (Ihlen, 2002) are among researchers who apply corporate apologia for certain crisis communication cases. iii. Rhetorical of renewal. Ulmer, Seeger \& Sellnow (2007) The latest informal pattern in communication crisis research is the rhetoric of reform. The difference between this pattern with corporate apologia and IRT is a positive perspective developed for the future of the organization rather than thinking about current conditions and discussion of responsibilities. The focus of the rhetorical of renewal is to help victims. The idea is that an organization finds new directions and goals that grow from the crisis. The four criteria used for reform include: 1) the organization has a strong pre-crisis ethical standard; 2) strong and profitable organizational constituent relations before the crisis; 3 ) the organization can focus on activities outside the crisis rather than finding faults; and 4) the organization wants to be involved in effective crisis communication. Renewal rhetoric includes events that occur before and during a crisis determine whether or not a crisis response is effective, and emphasizes the value and nature of positive crisis communication, along with an emphasis on recovery and the future of the organization. 


\section{Image Repair Theory}

Image Restoration Theory/Image Repair Theory The most productive framework for informal crisis communication research is image recovery theory, developed by William Benoit (1995, 2005). At the end of 2005 this framework became known as IRT. However, in 2008, Benoit and Pang called this framework an improvement to discourse theory or image improvement theory. Abbreviations and the core concepts of the theory remain the same, so they will only be referred to as IRT.

Benoit and Pang (2008) IRT begins with attacks that threaten reputation (what Benoit calls image). Attacks have two components: (a) the offensive act or (2) accusation of responsibility for the act or responsibility for the intended accusation/action. Offensive actions can be a threat to reputation. Become a threat when a person or organization is accused of being responsible and offensive. If there is no offensive action or no charge of responsibility for the action, there is no reputation threat.

Benoit (2005, p. 407) IRT is made to understand the communication options available to the public, whether organizations or people, who face threats to their reputation. IRT is not specifically developed for crisis communication, but can be implemented because a crisis is a threat to reputation. IRT uses communication to maintain reputation. IRT believes that communication aimed at positive organizational goals and reputation is one of the main goals of this communication.

Table 1. IRT Crisis Response Strategies

\begin{tabular}{|ll|}
\hline \multicolumn{1}{|c|}{ Denial } \\
\hline $\begin{array}{l}\text { i. } \\
\text { ii. }\end{array}$ & Simple Denial \\
\hline \multicolumn{1}{|c|}{ Evading Responsibility } \\
\hline i. & Provocation: respond to other people's actions \\
ii. & Defeasibility: lack of information about or control over the situation \\
iii. & Incidental: do not plan for an event to occur \\
iv. & Good intentions: act like a good party \\
\hline \multicolumn{1}{c}{ Reducing offensiveness } \\
\hline i. & Strengthening: reminding the quality / positive things that have been done \\
ii. & Minimize violations of action: claims for minor damage from the crisis \\
iii. & Differentiation: compares actions with similar events \\
iv. & Transcendence: place action in different contexts \\
v. & Attack Accuser \\
vi. & Corrective Action: restore the situation to status before acting and / or \\
& promise to change and prevent repeating that action \\
vii. Mortification: ask forgiveness; acknowledge guilt and express regret
\end{tabular}


Ulmer, Seeger \& Sellnow (2007) The latest informal pattern in communication crisis research is the rhetoric of reform. The difference between this pattern with corporate apologia and IRT is a positive perspective developed for the future of the organization rather than thinking about current conditions and discussion of responsibilities. The focus of the rhetorical of renewal is to help victims. The four criteria used for reform include: 1) the organization has a strong pre-crisis ethical standard; 2) strong and profitable organizational constituent relations before the crisis; 3 ) the organization can focus on activities outside the crisis rather than finding faults; and 4) the organization wants to be involved in effective crisis communication. Renewal rhetoric includes events that occur before and during a crisis determine whether or not a crisis response is effective, and emphasizes the value and nature of positive crisis communication, along with an emphasis on recovery and the future of the organization.

\section{Crisis in Higher Education}

Birnbaum and Shushok Jr. (2001) convey in detail the types of crises in Higher Education namely: 1) Pandemic Crisis or pandemic crisis: an event that occurs repeatedly with high frequency. For 25 years, finance has been a major pandemic crisis at tertiary institutions. 2) Chronic crisis or chronic crisis is a crisis that arises with varying continuity and frequency. This book identifies five chronic crises which include self-confidence, curriculum, stagnation (matters relating to the attitudes of universities that are not responsive to changing needs), diversity/equity, and government leadership/management. These things become routine discussions on the tertiary policy agenda. 3) Sporadic crisis is a crisis condition related to student riots, literacy/writing, values/morals and student registration. 4) Idiosyncratic crisis or a special crisis that is a crisis relating to things that are very specific. Some of them are related to accreditation, parking lots, to collective bargaining. Crisis that falls into this special category is often considered a common problem by most people, but tends to be an obstacle to organizational development.

\section{METHOD}

This research is an evaluative study with a qualitative approach. Evaluative research is basically part of applied research. According to Borg and Gall (2003) educational evaluation is the process of making judgments about the benefits, values, or balance of educational programs. McMillan and Schumacher (2010) explain that evaluation is one of the applications of research used to determine the success or failure or whether there are benefits/values of a program or policy in education. The interview method is often supplemented by documentation tracking. The aim is to obtain information that supports data analysis and interpretation. Documents can be in the form of public documents and private documents. In this study, researchers used public documents as research material. In this study, the 
researcher focused his research on the evaluation of crisis management at UB in 2010-2019 based on the viewpoints and opinions as well as the performance of the chancellor during his tenure. Researchers will use data sources regarding the crisis experienced by Universitas Brawijaya through news to provide in-depth interviews with the three Chancellors of Universitas Brawijaya Brawijaya University. And supporting data in the form of online news and e-complaints at the Information, Documentation and Complaints Center of Brawijaya University in the period 20102019. According to Sugiono (2008) data collection techniques are the most important step in a study, with the main objective of the research to obtain data that suits the needs of researchers. The several data collection techniques used in this study include; 1) Depth Interview; and 2) Document Study.

\section{RESULTS AND DISCUSSIONS}

\section{Crisis Characteristics}

In accordance with the opinion of Mitroff (2001) states that there are five general characteristics of a crisis which are then linked to the research theme, during the 20102019 period the characteristics of a crisis in Brawijaya University appear to be detrimental/affecting many people, having a beginning and end of events, relatively sudden, and not infrequently become the news and become the center of public attention. Furthermore, regarding the causes of crises based on Shirivasta and Mitroff (1999) which divides crises into four categories based on the causes of crises associated with crisis sites, the following are characteristics of crises in Universitas Brawijaya. 
Table 2. Typical Crisis Typology University of Brawijaya University 2010-2019

\begin{tabular}{|c|c|}
\hline $\begin{array}{l}\text { Cell } 1 \\
\text { Crisis caused by economic technical } \\
\text { failure: } \\
\text { a. Allegations of corruption } \\
\text { b. Alleged bribes for student } \\
\text { admission selection } \\
\text { c. Student tuition arrears }\end{array}$ & $\begin{array}{l}\text { Cell } 2 \\
\text { Crisis caused by technical/economic } \\
\text { factors that occur outside: } \\
\text { Demo/condemnation of prohibition of } \\
\text { discussions that are in conflict with legal } \\
\text { and religious norms }\end{array}$ \\
\hline Internal & External \\
\hline $\begin{array}{l}\text { Cell } 3 \\
\text { Crisis caused by social/human and } \\
\text { management factors originating from } \\
\text { institutions: } \\
\text { a. Crime: suicide, rape, killing a baby } \\
\text { b. Drug abuse } \\
\text { c. Student involvement in groups that } \\
\text { conflict with moral values / norms } \\
\text { d. The quality of human resources } \\
\text { and research results that have an } \\
\text { effect on ranking }\end{array}$ & $\begin{array}{l}\text { Cell } 4 \\
\text { Crises that occur due to social factors } \\
\text { outside the organizational environment, } \\
\text { namely the presence of people / groups } \\
\text { who react negatively: } \\
\text { a. National Narcotics Agency considers } \\
\text { Universitas Brawijaya as a potential } \\
\text { drug market } \\
\text { b. National Counterterrorism Agency } \\
\text { identifies the spread of the radicalism } \\
\text { virus in Brawijaya University } \\
\text { c. The fall in Universitas Brawijaya } \\
\text { ranking } \\
\text { d. Mugging } \\
\text { e. Traffic around the campus } \\
\text { environment. }\end{array}$ \\
\hline
\end{tabular}

\section{Response to Crisis}

As stated by Coombs (2010, p. 28) that response to crisis is the most researched aspect of crisis communication. The reason is how and what the organization communicates during a crisis has a significant influence on the crisis response including:

a. Tactical Advice or tactical suggestions by the leadership in UB is quite diverse, informant 1 tries to answer quickly, but has not been accompanied by data accuracy. This is evident from the statement in the interview, that in a number of cases encountered, informant 1 tended to direct the investigating party to directly contact the parties concerned with the problem, without conducting intensive coordination. In contrast to informant 1, informant 2 who continued the leadership relay was fully responsible for resolving the problems of the pre-existing institutions. Not only did they try to finish quickly, informant 2 also sought to solve accurately and consistently. This effort is seen with instructions given by informants 2 to parties potentially involved in several crises that are being 
faced to make a chronological record of events, create special teams, discuss with related parties, as well as look for efforts / solutions to resolve any problems. The performance of informant 2 was later adopted by informant 3, who in his tenure still continued the performance of the informant 2 formation team to overcome several crises within the institution. Similar to informant 2, informant 3 also sought to provide a fast, accurate, and consistent response in dealing with crisis.

b. Strategic Advice or the right advice is carried out in various ways. Informant 1 simply instructs staff / sections to provide information to those in need, and tends to face crises / problems privately rather than involving the organizational structure. Whereas informant 2 seeks to instruct information through the formation of a special team, which certainly plays a role in enriching the information needed to respond to a crisis, and in terms of restoring the reputation of the institution. Adopting the performance of informant 2, informant 3 also sought to carry out strategic advice thoroughly through a special team including informant 7 who worked as a public relations leader.

c. Corporate Apology. Through the interview results it was found that informant 1 in 2010-2014 chose to use denial and bolstering strategies. Whereas in 2014-2019, informant 2 and informant 3 often used bolstering, differentiation and transcendce strategies.

d. Rhetorical of renewal, through research, during the 3 rector's leadership it was known that in 2010-2014 Brawijaya University did not yet have strong pre-crisis standards, organizational relationships that were merely formal in accordance with their structure, duties and positions, and were not yet involved in effective crisis communication. However, through the leadership of the informants, Universitas Brawijaya can focus on the achievements and targets of the institution. Furthermore, in 2014-2018 under the leadership of informant 2, Universitas Brawijaya had a good standard of pre-crisis ethics, solid inter-agency relations, which influenced the ease of establishing institutional activities and effective crisis communication efforts. Continuing the performance of informant 2, not much different, informant 3 can do the overall criteria that have been applied before, but with a different perspective on the crisis, matters relating to the standard ethics of pre-crisis did not get a dominant portion during his leadership.

\section{Image Repair Theory}

In accordance with Image Restoration Theory / Image Repair Theory, the most productive framework for informal crisis communication research is image recovery theory, developed by William Benoit $(1995,2005)$. At the end of 2005 this 
framework became known as IRT. However, in 2008, Benoit and Pang called this framework an improvement to discourse theory or image improvement theory. Abbreviations and the core concepts of the theory remain the same, so they will only be referred to as IRT. The researcher adopts a crisis response strategy table and seeks to categorize crisis response strategies in UB as follows:

Table of IRT Crisis Response Strategies at Brawijaya University

\begin{tabular}{|c|c|c|c|}
\hline \multirow[t]{2}{*}{ Strategies } & \multicolumn{3}{|c|}{ Year } \\
\hline & $\begin{array}{c}2010-2014 \\
\text { (Informant 1) }\end{array}$ & $\begin{array}{c}\text { 2014-2018 } \\
\text { (Informant 2) }\end{array}$ & $\begin{array}{c}\text { 2018-2019 } \\
\text { (Informant 3) }\end{array}$ \\
\hline \multicolumn{4}{|c|}{ Denial } \\
\hline i. Simple Denial & $\checkmark$ & $\times$ & $\checkmark$ \\
\hline ii. Shift the Blame & $\checkmark$ & $x$ & $\checkmark$ \\
\hline \multicolumn{4}{|c|}{ Evading Responsibility } \\
\hline $\begin{array}{l}\text { i. Provocation: respond to other } \\
\text { people's actions }\end{array}$ & $\times$ & $\checkmark$ & $\checkmark$ \\
\hline $\begin{array}{l}\text { ii. Defeasibility: lack of } \\
\text { information about or control } \\
\text { over the situation }\end{array}$ & $\checkmark$ & $x$ & $\times$ \\
\hline $\begin{array}{l}\text { iii. Incidental: do not plan for an } \\
\text { event to occur }\end{array}$ & $\checkmark$ & $x$ & $\checkmark$ \\
\hline $\begin{array}{l}\text { iv. Good intentions: act like a } \\
\text { good party }\end{array}$ & $\checkmark$ & $\checkmark$ & $\checkmark$ \\
\hline \multicolumn{4}{|c|}{ Reducing offensiveness } \\
\hline $\begin{array}{l}\text { i. Strengthening: reminding the } \\
\text { quality/positive things that } \\
\text { have been done }\end{array}$ & $\checkmark$ & $\checkmark$ & $\checkmark$ \\
\hline $\begin{array}{l}\text { ii. Minimize violations of action: } \\
\text { claims for minor damage from } \\
\text { the crisis }\end{array}$ & $x$ & $\checkmark$ & $\checkmark$ \\
\hline $\begin{array}{l}\text { iii. Differentiation: compares } \\
\text { actions with similar events }\end{array}$ & $\checkmark$ & $x$ & $\checkmark$ \\
\hline $\begin{array}{l}\text { iv. Transcendence: place action in } \\
\text { different contexts }\end{array}$ & $\checkmark$ & $\checkmark$ & $\checkmark$ \\
\hline v. Attack Accuser & $\checkmark$ & $x$ & $\checkmark$ \\
\hline $\begin{array}{l}\text { vi. Corrective Action: restore the } \\
\text { situation to status before acting } \\
\text { and/or promise to change and } \\
\text { prevent repeating that action }\end{array}$ & $\checkmark$ & $\checkmark$ & $\checkmark$ \\
\hline $\begin{array}{l}\text { vii. Mortification: ask forgiveness; } \\
\text { acknowledge guilt and express }\end{array}$ & $x$ & $\checkmark$ & $\checkmark$ \\
\hline regret & $x$ & $\checkmark$ & $x$ \\
\hline
\end{tabular}


Researchers adopted a crisis response strategy table to categorize crisis response strategy responses in Universitas Brawijaya. Based on the above table, it is known that the understanding of the crisis of higher education also influences each informant in conducting strategies to respond to the crisis, it appears that at the denial stage or denial used by informant 1 and informant 3 . In several reports or problems, informant 1 often states in interviews with researchers that the person concerned was not involved or conveyed that there were other parties who were more responsible / involved in relation to the problem or initial findings submitted by the researcher. Different things appear in informant 2, when the researcher delivered a number of findings actually responded openly and responded in accordance with experience and knowledge regarding the crisis. At the stage of evading responsibility with details of responding to the actions of others, lack of information about or control of the situation, not planning for an event to occur, and behaving like a good party, it is mostly done by informant 3 and informant 1, while informant 2 only uses strategies to respond to actions and show good faith in responding to the crisis. Overall informant 1 does not respond to the actions of other parties when negative news/events occur, but on the other hand informant 1 also has limited information that impacts on the lack of ability to exercise control to appear/spread the news in public, does not plan preparation for the occurrence of negative events that can has a big impact on the agency, and on the other hand continues to carry out a series of activities that are expected to have a good impact on the institution. Unlike informant 1, informant 2 responds to the actions of other parties as a form of institutional response, which is complemented by efforts to provide adequate information to various related parties, including preparing plans for unexpected events, and continuing to do good things for the public. Slightly different from informant 2, although acknowledging that many adopted the breakthroughs produced by informant 2, based on the results of the interview it is known that informant 3 responds to the actions of other parties, and can provide information adequacy by using existing special teams, which at the same time are able to suppress the occurrence of unplanned events, and keep trying to show good faith from the agency.

The next stage, namely reducing offensiveness or reducing attacks carried out at most by informant 3, although differing in the perspective of informant 1 and informant 2 has a balance in an effort to reduce attacks. The difference is, informant 1 tends to use selfdefense measures, while informant 2 attempts to carry out evaluative and solutive actions. In detail, efforts to reduce attacks carried out during office by informant 1 were to provide information on the amount of work during his term of office, to compare similar incidents in several institutions which were then considered normal and ordinary events, to take the same actions for the institution's objectives, to oppose opinions about the crisis itself, as well as offering compensation for the events at hand. Informant 1 also did not make an effort to minimize actions 
that were not in accordance with the basic regulations in an effort to reach the target of the institution, had not done anything corrective, or expressed remorse. At this stage the efforts made by informants 2 by conveying the achievements that have been made, minimizing the occurrence of violations, responding to an event quickly in the hope that it can be interpreted widely by related parties, make corrective efforts to improve the situation, and submit apologies if needed. During the interview, the researcher also found that informant 2 did not make an effort to compare the crisis faced with similar events, including not avoiding the occurrence of a crisis on the body of the institution, and in some cases finding solutions or alternatives with matters relating to finance. Furthermore, in practice, informant 3 often provides confirmation of positive things done by the agency, including following applicable regulations, also conveys some similar events, carrying out a series of activities to get a good image. On the other hand, informant 3 ward off a crisis, by taking corrective actions without carrying out mortification (statement of regret). Based on the details of the presentation, it is known that the understanding of the crisis of universities specifically influences the efforts made by the leadership of the institution in responding to the crisis itself. Good understanding has an impact on the right handling of crises to save institutions as well as being an effort to suppress a greater crisis.

\section{Higher Education Crisis}

Based on research data obtained by the crisis in Brawijaya University include 1) Grouped pandemic crisis related to finance, corruption, drug use and cultivation; 2) Sporadic crises related to behavior / morals and labeling Universitas Brawijaya as a campus with negative images; 3) Chronic crisis related to the findings of suicide students, as well as; 4) A special crisis related to UB's ranking, crime-prone locations, and campus findings with radicalism. When the researcher confirmed to informant 3 as the chancellor who was still in office when this research was conducted in order to find out the crisis management plan at Brawijaya University in 2020-2025, as quoted in the previous discussion, informant 3 tended to make efforts to handle an event that was being faced / is in plain sight, or termed "ketok moto management". However, with a number of crisis management efforts inherited by the previous chancellor, several events assessed by researchers can be accommodated through a special team that is believed to have competence, namely the Bureaucracy Reform Team, as well as in terms of public relations, the current public relations leader, namely informant 7 has experience and ability to understand crises in tertiary institutions that can respond quickly when a crisis occurs or the potential crisis itself.

\section{E. CONCLUSION}

Through various literature review presentations and research findings found in a series of data collection activities, namely interviews and document studies as 
explained in the previous chapters, the author concludes several results from this research including:

1. Regarding the view of the rector of Universitas Brawijaya during his term of office regarding crisis management at Universitas Brawijaya, it is known that each rector has a variety of understandings about a number of news items and problems faced during his tenure. Two leaders who did not interpret the problems faced as a crisis, namely Prof. Ir. Yogi Sugito, MS (informant 1) and Prof. Ir. Nuhfil Hanani, AR, MS (informant 3). It is known from the data obtained that although a number of data were found which later influenced the development of the institution in the long term, including being an obstacle in the development of Universitas Brawijaya in the following years, it was not suspected of being a crisis by the two informants. For example, in facing the challenges of limited institutional funds and heard the efforts to develop institutions that are not in accordance with applicable regulations. Next, understanding that all problems faced are not a crisis and then interpreted by researchers related to tenure has just been carried out by informant 3, so that they feel in a safe condition when leading up to this research, while the challenges being faced are related to efforts to make Universitas Brawijaya as autonomous and internationally reputable universities and the occurrence of crises related to Covid 19 when this research was conducted. Different points of view found from Prof. Dr. Ir Muhammad Bisri, MS (informant 2). Based on the results of interviews, it is known that the ability to understand the crisis of tertiary institutions faced by institutions and make efforts to resolve in a structured manner with competent parties. The challenges faced by informants 2 while serving included demands to tidy up licensing of various faculties and study programs, as well as regulating the number of students that exceeded the limit. Together with his staff, informant 2 sought to tidy up internal and external problems. The researcher then concluded based on the results of the interview that the performance in the 2014-2018 period was the time for handling the crisis management evaluation at Brawijaya University which was the most ideal, because the main leaders understood the crisis of the university well, and used a management system which was then implemented for crisis prevention and handling, and also supported by giving a portion and trust to the leadership of public relations to scan, examine, deal with and resolve a number of crises in the body of the organization, which are not only measured by the emergence of negative news in the mass media. In these years the concept of online public relations has also begun to be initiated by activating a variety of UB's official social media which is expected to become an official and trusted source of information for Universitas Brawijaya. However the evaluative stage has not 
been specifically thought to obtain references in tackling similar problems / crises in the coming years, the focus of crisis resolution is still prioritizing matters relating to administrative regulations, legal norms, and efforts to suppress the emergence of greater coverage. Based on the details of the presentation, it is known that the understanding of the crisis of universities specifically influences the efforts made by the leadership of the institution in responding to the crisis itself. Good understanding has an impact on the right handling of crises to save institutions as well as being an effort to suppress a greater crisis.

2. In accordance with the research theme "UB Crisis Management in 2010-2019" the researcher can conclude that crisis management in UB in 2010-2019 is known that from all informants, there is one in three informants who really understand the crisis in As stated in the literature review, two informants who did not yet understand the college crisis had an effect on their performance. This then gives an impact on the policies or efforts made in dealing with a variety of negative events at UB. Ideally, public relations has its own part, not combined with other divisions / sections. This means that public relations is not subordinated by other divisions, or public relations belongs to the upper structure (dominant coalition), unfortunately for a period of 10 years the public relations structure at UB is dynamic following the direction of government policy. Based on the researcher's interview, it is known that the strategic position of public relations influences efforts in handling crises in UB, this is also supported by the capability/competence of the leadership of public relations, as well as instructions given by the chancellor in dealing with various crises/problems. This is directly proportional in the decision making effort, including in order to give advice to the leadership. It is known that only one of the many public relations leaders during 2010-2019 gained the discretion to make decisions or provide advice, while overall public relations at Universitas Brawijaya was given the main portion of trust to face and foster good relations with media partners. So it can be concluded that the crisis management of 20102019 has not been carried out appropriately and comprehensively, but is partial in adjusting to the needs of handling, and has not paid attention to the interests of all related parties (internal and external public).

\section{REFERENCES}

1. Benoit, W. L. (1995). Accounts, excuses, and apologies: A theory of image restoration strategies. Marcombo.

2. Benoit, W. L., \& Pang, A. (2008). Crisis communication and image repair discourse.

3. Birnbaum, R., \& Shushok Jr, F. (2001). The "crisis" crisis in higher education. In Defense of American Higher Education, 59-84. 
4. Blaxter, L., \& Tight, M. (1994). Juggling with Time: How Adults Manage their Time for Lifelong Education. Studies in the Education of Adults, 26(2), 162-179. https://doi.org/10.1080/02660830.1994.11730604

5. Feoktistova, Y. (n.d.). A Model of Enterpreneurship Education. Журнал Зарегистрирован в Министерстве Культуры, Информации и Спорта РК. Свидетельство о Постановке На Учет СМИ № 5888-ж От 11.04. 2005. Журнал Включен в Перечень Научных Изданий Комитета По Контролю в Сфере Образования и Науки МОН РК, Рекомендованных, Для, 11(05), 35.

6. Hearit, K. M. (2006). Crisis Management By Apology. In Crisis Management By Apology.

7. Ice, R. (1991). Corporate publics and rhetorical strategies: The case of Union Carbide's Bhopal crisis. Management Communication Quarterly, 4(3), 341-362.

8. Kriyantono, R. (2015). Public Relations, Issue E Crisis Management: Pendekatan Critical Public Relation, Etnografi Kritis \& Kualitatif. Kencana.

9. Maleong, L. J. (2006). Metodologi Penelitian Kualitatif. Bandung: Remaja Rosdakarya.

10. Muralidharan, S., Rasmussen, L., Patterson, D., \& Shin, J. H. (2011). Hope for Haiti: An analysis of Facebook and Twitter usage during the earthquake relief efforts. Public Relations Review, 37(2), 175-177. https://doi.org/10.1016/j.pubrev.2011.01.010

11. Mitroff, I. I. (2001). Crisis leadership. Executive Excellence, 18(8), 19.

12. Nasution, Z. (2010). Manajemen humas di lembaga pendidikan: konsep, fenomena, dan aplikasinya. Universitas Muhammadiyah Malang Press.

13. Ross, M., \& Fletcher, G. J. O. (1985). Attribution and social perception. The Handbook of Social Psychology, 2, 73-114.

14. Salmi, J. (1991). The Higher Education Crisis in Developing Countries: Issues. Problems, Constraints and Reforms," Paper Presented at the 1991 Course on Sociology of Science, Inter-University Centre, Dubrovnik, Yugoslavia.

15. Sellnow, D. D., Lane, D., Littlefield, R. S., Sellnow, T. L., Wilson, B., Beauchamp, K., \& Venette, S. (2015). A Receiver-Based Approach to Effective Instructional Crisis Communication. Journal of Contingencies and Crisis Management, 23(3), 149-158. https://doi.org/10.1111/14685973.12066

16. Sturges, D. L. (1994). Communicating through crisis: A strategy for organizational survival. Management Communication Quarterly, 7(3), 297-316.

17. Ulmer, R. R., Seeger, M. W., \& Sellnow, T. L. (2007). Post-crisis communication and renewal: Expanding the parameters of post-crisis discourse. Public Relations Review, 33(2), 130-134.

18. Zamani, E. M. (2003). African American women in higher education. New Directions for Student Services, 2003(104), 5-18. https://doi.org/10.1002/ss.103 